\title{
Is Psoriatic Arthritis Associated With Higher Risk of Mortality?
}

\author{
Ying-Ying Leung ${ }^{1}$ (I)
}

Psoriatic arthritis (PsA) is a systemic inflammatory disease affecting domains beyond the musculoskeletal system, and may lead to disability and impaired quality of life. It is associated with comorbidities such as hypertension, diabetes mellitus, obesity, metabolic syndrome, and increased risk of cardiovascular events. Studies on whether PsA may lead to higher mortality are still controversial. Earlier studies from tertiary rheumatology centers have revealed an increase in mortality among patients with PsA compared to the general population, whereas more recent studies did not reveal an increased risk. It is also unclear whether an observed increased morality in patients with PsA is due to the association between PsA and cardiovascular risk factors, or to PsA per se.

In this issue of The Journal of Rheumatology, Haddad et al reported the results of a large population-based cohort study on 5275 patients with PsA compared to 21,011 controls after a mean follow-up of 7.2 years in Israel. ${ }^{1}$ The authors found no increased risk in all-cause mortality in patients with PsA compared to those without, after adjustment of comorbidities. The leading cause of death was malignancy, followed by ischemic heart disease; this was in line with the order of the causes of death in the general population. The strength of this study lies in the large sample size and data from a population-based cohort, the Clalit Health Services, which is the largest healthcare provider in Israel, covering $52 \%$ of Israel's population. A rich dataset including demographics, smoking, BMI, comorbidities, and use of conventional (c-) and biologic (b-) disease-modifying antirheumatic drugs (DMARDs) was collected. As the association of PsA with metabolic comorbidities and ischemic heart disease

YYL is supported by the National Medical Research Council, Singapore (NMRC/CSA-Inv/0022/2017). The funding sources had no role in views expressed in this editorial.

${ }^{1} Y . Y$. Leung, MBChB, MD, Department of Rheumatology and Immunology, Singapore General Hospital, and Duke-NUS Medical School, Singapore.

$Y Y L$ has received speaker fees from AbbVie, DKSH, Janssen, Novartis, and Pfizer.

Address correspondence to Dr. Y.Y. Leung, Department of Rheumatology and Immunology, Singapore General Hospital, The Academia, Level 4, 20 College Road, Singapore 169856.Email:katyccc@hotmail.com.

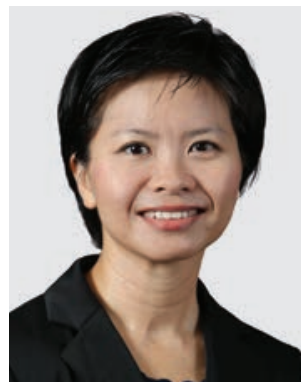

is well known, the controlling of these confounding variables allows the evaluation of PsA as an independent risk to mortality.

The disparity of results regarding the association between PsA and risk of mortality is related to 3 main groups of bias classically described in epidemiology studies: information bias, selection bias, and confounding. ${ }^{2}$ Information bias relates to how cases or controls are being classified or misclassified in studies. Many cohort studies reported the standardized mortality ratio (SMR), which compared the observed number of deaths arising in a PsA cohort with the expected number of deaths in the general population, standardized to age, sex, and calendar time period. The assumption is that the death rate in the general population reflects the death rate that would occur in individuals without PsA. However, it is usually not possible to exclude cases of PsA from the data that generated the SMR, thereby introducing information bias in such studies. This bias can be substantial, particularly for diseases with a high prevalence. ${ }^{3}$ Arguably, this bias may be trivial given that PsA is an uncommon disease. Cohort studies that utilize an internal comparison within the same dataset, with careful verification of PsA cases vs noncases, would be more objective. ${ }^{4}$

Selection bias arises when the study population does not represent the target population. Studies in patients with PsA identified from secondary or tertiary rheumatology centers represent a subgroup of patients with the most severe spectrum of PsA and may have overestimated the risk of mortality $y^{5,6,7,8,9,10}$ (Table 1), whereas PsA cases identified from primary care registries and population-based registries should be generalized to a broader spectrum of individuals with the disease (Table 2). Many of the patients from these population-based registries or primary healthcare registries may not have been seen by rheumatologists or other specialists. Data from the University of Toronto PsA cohort showed elevated SMRs compared to the general population during 1978-1993..$^{5}$ In follow-up studies of the same cohort over the subsequent 4 decades, a trend of reduction in SMRs has been reported. ${ }^{6,7}$ The overall SMRs were $1.89(95 \%$ CI 1.25-2.87), 1.63 (95\% CI 1.19-2.24), and 1.05 (95\% CI 0.79-1.41) for the calendar time periods 1978-1986,

See Mortality in PsA, page xxx

(C) 2021 The Journal of Rheumatology

Leung 
Table 1. Mortality studies using patients with PsA from hospital cohorts.

\begin{tabular}{|c|c|c|c|c|c|c|}
\hline Author, Yr & Study Period & Country & $\begin{array}{l}\text { Source of PsA Cases } \\
\quad \text { (Sample Size })\end{array}$ & Comparison & Matching Variables & Mortality Risk Ratio (95\% CI) \\
\hline Wong, $1997^{5}$ & $1978-1993$ & Canada & $\begin{array}{l}\text { Tertiary rheumatology } \\
\text { referral center }(428)\end{array}$ & $\begin{array}{l}\text { General population } \\
\quad(\text { external })\end{array}$ & $\begin{array}{l}\text { Age categories, sex, } \\
\text { calendar period }\end{array}$ & $\begin{array}{l}\text { SMR } 1.62(1.21-2.12) \\
\cdot \text { Men: } 1.65(1.09-2.40) \\
\text {. Women: } 1.59(1.04-2.33)\end{array}$ \\
\hline Ali, $2007^{6}$ & $1978-2004$ & Canada & $\begin{array}{l}\text { Tertiary rheumatology } \\
\text { referral center }(680)\end{array}$ & $\begin{array}{l}\text { General population } \\
\quad(\text { external })\end{array}$ & $\begin{array}{l}\text { Age categories, sex, } \\
\text { calendar period }\end{array}$ & $\begin{array}{l}\text { SMR } 1.36(\mathbf{1 . 1 2 - 1 . 6 4 )} \\
\cdot \text { Men: } 1.25(0.95-1.65) \\
\text {. Women: } \mathbf{1 . 4 7}(\mathbf{1 . 1 3 - 1 . 9 1 )}\end{array}$ \\
\hline Elalouf, $2020^{7}$ & $1978-2017$ & Canada & $\begin{array}{l}\text { Tertiary rheumatology } \\
\text { referral center }(1490)\end{array}$ & $\begin{array}{l}\text { General population } \\
\quad(\text { external })\end{array}$ & $\begin{array}{l}\text { Age categories, sex, } \\
\text { calendar period }\end{array}$ & $\begin{array}{l}\text { SMR 0.92 }(0.80-1.05) \\
\cdot \quad \text { Men: } 0.80(0.66-0.97) \\
\cdot \text { Women: } 1.08(0.89-1.30) \\
\text { Age-specific SMR } \\
\cdot \quad \mathbf{2 0 - 3 9 : ~} 3.36(\mathbf{1 . 6 1 - 8 . 1 8}) \\
\cdot \quad 40-59: 0.97(0.68-1.34) \\
\cdot \quad 60-79: 0.88(0.73-1.06) \\
\cdot \geq 80: 0.86(0.66-1.10)\end{array}$ \\
\hline Mok, $2011^{9}$ & 1999-2008 & Hong Kong & Hospital cohort (778) & $\begin{array}{l}\text { General population } \\
\quad(\text { external })\end{array}$ & $\begin{array}{l}\text { Age categories, sex, } \\
\text { calendar period }\end{array}$ & $\begin{array}{l}\text { SMR 1.59 (1.16-2.03) } \\
\cdot \text { Men: } 1.40(0.89-1.90) \\
\text { · Women: } \mathbf{1 . 9 6}(\mathbf{1 . 1 4 - 2 . 7 7 )}\end{array}$ \\
\hline Juneblad, $2016^{10}$ & 1995-2011 & Sweden & $\begin{array}{l}\text { Cohort under rheumatologist } \\
\text { care }(464)\end{array}$ & $\begin{array}{l}\text { General population } \\
\quad(\text { external })\end{array}$ & $\begin{array}{l}\text { Age categories, sex, } \\
\text { calendar period }\end{array}$ & $\begin{array}{l}\text { SMR } 1.22(0.89-1.63) \\
\text { No sex difference (data not } \\
\text { shown) }\end{array}$ \\
\hline
\end{tabular}

Values in bold show statistically significantly higher mortality compared to controls. SMR: standardized mortality ratio; PsA: psoriatic arthritis.

1987-1995, and 1996-2004, respectively, ${ }^{6}$ and no increase in mortality (SMR 0.92, 95\% CI 0.80-1.05) was observed in the period of 1978-2017 (Table 1). The observed reduction in SMR may be related to earlier diagnosis and improvement in treatment over time.

Similar to the study from Israel by Haddad et al, ${ }^{1}$ Ogdie et al and Skov et al reported no increased risk in mortality among patients with PsA compared to those without, using the UK general practitioner THIN database and the Danish National Patient Registry, respectively. ${ }^{11,12}$ These population-based cohort studies usually have bigger sample sizes, and comparison of PsA cases and noncases comes from the same cohort (Table 2). Yet, some population-based cohort studies still report an excess risk of mortality among patients with PsA, including that derived from the Taiwan nationwide health insurance registry ${ }^{13,14}$ and the Ontario Health Insurance Plan. ${ }^{15}$

Another major source of bias may arise from residual confounding factors. Mortality studies using SMRs comparing PsA cohorts to the general population can only standardize or match the comparison with age, sex, and calendar year. Metabolic and cardiovascular comorbidities among patients with PsA are prevalent. As Haddad et al have shown in the current issue, more patients with PsA were smokers, were obese, and had diabetes, hypertension, dyslipidemia, history of ischemic heart disease, cerebrovascular disease, congestive heart failure, chronic obstructive pulmonary disease, chronic renal failure, and cirrhosis than the control population. ${ }^{1}$ These factors are themselves associated with higher risk of mortality, causing confounding or mediation effects in the evaluation of the association of mortality from PsA itself. A mediator is a variable that lies in the causative pathway between the exposure and outcome. Studies comparing mortality rates in PsA cohorts with external populations would make adjustment of these confounding factors or mediators impossible. It may be a reasonable model to study the total effect of PsA together with all the associated morbidities on mortality, but these studies would be unable to inform on whether PsA itself is associated with higher risk of death. Using a time-varying statistical model, Haddad et al have illustrated nicely the drop in HR for risk of mortality from 1.16 (95\% CI $1.04-1.29)$ to 1.02 (95\% CI 0.90-1.15) when these comorbidities were adjusted. ${ }^{1}$

There is evidence to suggest that PsA itself may be associated with higher mortality. A metaanalysis among patients with psoriasis showed an increased risk for all-cause mortality and cause-specific mortality compared to those without, and the increased risk of mortality was more prominently seen in those with severe psoriasis compared to mild psoriasis. ${ }^{16}$ This dose-dependent relationship implies that burden of psoriatic disease itself may be related to higher risk of mortality. However, none of the cohort studies in PsA on mortality so far have collected information on disease activity. Current evidence does suggest that increased mortality is observed when it is least expected, such as in younger age group ${ }^{7,15,17}$ and in women. ${ }^{6.9}$ In the sensitivity analysis, Haddad et al have evaluated use of DMARDs and found that treatment with cDMARDs was associated with a lower HR of death, whereas treatment 
Table 2. Mortality studies PsA cases and control from population-based cohorts.

\begin{tabular}{|c|c|c|c|c|c|c|c|}
\hline $\begin{array}{l}\text { Author, } \\
\text { Yr }\end{array}$ & $\begin{array}{l}\text { Study } \\
\text { Period }\end{array}$ & Country & $\begin{array}{c}\text { Source of } \\
\text { PsA Cases } \\
\text { (Sample Size) }\end{array}$ & $\begin{array}{l}\text { Comparison } \\
\text { Controls } \\
\text { (Sample Size) }\end{array}$ & $\begin{array}{c}\text { Source of } \\
\text { Comparison }\end{array}$ & $\begin{array}{c}\text { Matching or } \\
\text { Adjustment Variables }\end{array}$ & Mortality Risk Ratio (95\% CI) \\
\hline $\begin{array}{l}\text { Ahlehoff, } \\
2011^{17}\end{array}$ & $1997-2006$ & Denmark & $\begin{array}{l}\text { Population- } \\
\text { based }(607)\end{array}$ & $\begin{array}{l}\text { Nationwide } \\
\text { registry }(4,003,265) \\
\text { Propensity score } \\
\text { matched controls } \\
(36,992)\end{array}$ & Internal & $\begin{array}{c}\text { Matching with propensity } \\
\text { scoring: age, sex, comorbidities, } \\
\text { medical treatments (e.g., platelet } \\
\text { inhibitors, antihypertensives, statins) }\end{array}$ & $\begin{array}{l}\text { RR } 1.74(1.32-2.30)^{\mathrm{a}} \\
\text { Age-specific RR, yrs } \\
\cdot \quad \mathbf{1 8 - 5 0 : 2 . 2 3 ( 1 . 0 6 - 4 . 6 9 )} \\
\cdot \quad \mathbf{5 1 - 7 0 : 1 . 8 7 ( 1 . 2 7 - 2 . 7 4 )} \\
. \quad>70: 1.43(0.88-2.34)\end{array}$ \\
\hline $\begin{array}{l}\text { Ogdie, } \\
2014^{11}\end{array}$ & 1994-2010 & UK & $\begin{array}{l}\text { Population- } \\
\text { based (8706) }\end{array}$ & $\begin{array}{c}\text { Population-based } \\
\text { GP registry }(82,258)\end{array}$ & Internal & $\begin{array}{l}\text { Age- and sex-matched } \\
\text { Adjustment variables: Charlson } \\
\text { comorbidity score, smoking, } \\
\text { BMI, blood pressure at baseline, } \\
\text { depression, prior hospitalization, } \\
\text { year of cohort entry, socioeconomic } \\
\text { status, urban vs rural dwelling, } \\
\text { DMARD use }\end{array}$ & $\begin{array}{l}\text { HR } 1.02(0.92-1.12)^{\mathrm{b}} \\
\cdot \quad \text { DMARD users: } 0.94(0.80-1.10) \\
\cdot \quad \text { DMARD nonusers: } 1.06(0.94-1.19)\end{array}$ \\
\hline Lee, $2017^{13}$ & $2001-2012$ & Taiwan & $\begin{array}{l}\text { Population- } \\
\text { based (9572) }\end{array}$ & $\begin{array}{l}\text { Nationwide } \\
\text { population-based } \\
\text { health insurance } \\
\text { database }\end{array}$ & Internal & Age categories, sex-matched & $\begin{array}{l}\text { SMR } 1.47(1.36-1.58) \\
\cdot \quad \text { Men: } 1.53(1.39-1.66) \\
. \quad \text { Women: } 1.32(1.12-1.51)\end{array}$ \\
\hline Dai, $2018^{14}$ & $2000-2012$ & Taiwan & $\begin{array}{l}\text { Population- } \\
\text { based ( } 8795)\end{array}$ & $\begin{array}{c}\text { Nationwide } \\
\text { population-based } \\
\text { health insurance } \\
\text { database }\end{array}$ & Internal & $\begin{array}{l}\text { Age-, sex-matched } \\
\text { Adjustment variables: age, sex, } \\
\text { socioeconomic status, urban vs } \\
\text { rural dwelling, comorbidities }\end{array}$ & HR $1.52(1.39-1.66)$ \\
\hline Skov, $2019^{12}$ & $1998-2014$ & Denmark & $\begin{array}{c}\text { Secondary } \\
\text { healthcare registry } \\
(9817)\end{array}$ & $\begin{array}{c}\text { Nationwide } \\
\text { population- } \\
\text { based registry } \\
(19,398)\end{array}$ & External & $\begin{array}{l}\text { Age, sex, marital status, } \\
\text { municipality-matched }\end{array}$ & Stratified HR $1.06(P=0.19)$ \\
\hline $\begin{array}{l}\text { Haddad, } \\
2021^{1}\end{array}$ & $2003-2018$ & Israel & $\begin{array}{l}\text { Population- } \\
\text { based (5275) }\end{array}$ & $\begin{array}{l}\text { Population- } \\
\text { based health } \\
\text { insurance } \\
\text { database }(21,011)\end{array}$ & Internal & $\begin{array}{l}\text { Adjustment variables: age, sex, } \\
\text { ethnicity, socioeconomic status, } \\
\text { obesity, comorbidities, history of } \\
\text { hospitalization } 1 \text { year prior }\end{array}$ & $\begin{array}{l}\text { Crude HR: } \mathbf{1 . 1 6}(\mathbf{1 . 0 4}-\mathbf{1 . 2 9}) \\
\text { Adjusted HR: } 1.02(0.90-1.15)\end{array}$ \\
\hline
\end{tabular}

Values in bold show statistically significantly higher mortality compared to controls. ${ }^{a}$ Results similar in propensity scoring matched analysis (data not shown). ${ }^{\mathrm{b}}$ Other variables tested did not change the model results (data not shown). DMARD: disease-modifying antirheumatic drugs; GP: general practitioners; PsA: psoriatic arthritis; RR: rate ratio; SMR: standardized mortality ratio.

with bDMARDs was associated with a similar trend but was not statistically significant. This may indicate a reduction of mortality with treatment optimization, but this is less achievable for those with severe disease who require bDMARDs. ${ }^{1}$

Evidence on whether PsA is associated with mortality in PsA remains conflicting. Disparity in the results of mortality studies in PsA can be explained by classically described potential bias in study design: information bias, selection bias, and residual confounding. Population-based studies have the advantage of including PsA patients with a broader disease spectrum, comparing PsA cases vs non-PsA cases from the same cohort, and collecting relevant comorbidities for adjust- ments of confounders. These population-based cohort studies will continue to improve our understanding on whether it is PsA or its comorbidities that are causing increased mortality. A trend of reduction in the excess mortality risk over time has been reported that may possibly be related to improved treatment and care plans. In addition to early diagnosis and optimizing control of disease activity, management of lifestyle risk factors and comorbidities among patients with PsA should be advocated.

\section{REFERENCES}

1. Haddad A, Saliba W, Lavi I, et al. The association of psoriatic 
arthritis with all-cause mortality and leading causes of death in psoriatic arthritis. J Rheumatol xxxxxxxxxx.

2. Kleinbaum DG, Kupper LL, Morgenstern H. Epidemiologic research: principles and quantitative methods. John Wiley \& Sons; 1982.

3. Jones ME, Swerdlow AJ. Bias in the standardized mortality ratio when using general population rates to estimate expected number of deaths. Am J Epidemiol 1998;148:1012-7.

4. Card TR, Solaymani-Dodaran M, Hubbard R, Logan RF, West $\mathrm{J}$. Is an internal comparison better than using national data when estimating mortality in longitudinal studies? J Epidemiol Community Health 2006;60:819-21.

5. Wong K, Gladman DD, Husted J, Long JA, Farewell VT. Mortality studies in psoriatic arthritis: results from a single outpatient clinic. I. Causes and risk of death. Arthritis Rheum 1997;40:1868-72.

6. Ali Y, Tom BD, Schentag CT, Farewell VT, Gladman DD. Improved survival in psoriatic arthritis with calendar time. Arthritis Rheum 2007;56:2708-14.

7. Elalouf O, Muntyanu A, Polachek A, et al. Mortality in psoriatic arthritis: risk, causes of death, predictors for death. Semin Arthritis Rheum 2020;50:571-5.

8. Buckley C, Cavill C, Taylor G, et al. Mortality in psoriatic arthritis a single-center study from the UK. J Rheumatol 2010;37:2141-4.

9. Mok CC, Kwok CL, Ho LY, Chan PT, Yip SF. Life expectancy, standardized mortality ratios, and causes of death in six rheumatic diseases in Hong Kong, China. Arthritis Rheum 2011;63:1182-9.

10. Juneblad K, Rantapaa-Dahlqvist S, Alenius GM. Disease activity and increased risk of cardiovascular death among patients with psoriatic arthritis. J Rheumatol 2016;43:2155-61.
11. Ogdie A, Haynes K, Troxel AB, et al. Risk of mortality in patients with psoriatic arthritis, rheumatoid arthritis and psoriasis: a longitudinal cohort study. Ann Rheum Dis 2014;73:149-53.

12. Skov L, Thomsen SF, Kristensen LE, Dodge R, Hedegaard MS, Kjellberg J. Cause-specific mortality in patients with psoriasis and psoriatic arthritis. Br J Dermatol 2019;180:100-7.

13. Lee MS, Yeh YC, Chang YT, Lai MS. All-cause and cause-specific mortality in patients with psoriasis in Taiwan: a nationwide population-based study. J Invest Dermatol 2017;137:1468-73.

14. Dai YX, Hsu MC, Hu HY, et al. The risk of mortality among psoriatic patients with varying severity: a nationwide populationbased cohort study in Taiwan. Int J Environ Res Public Health 2018;15:2622.

15. Colaco K, Widdifield J, Luo J, et al. Trends in mortality and cause-specific mortality among patients with psoriasis and psoriatic arthritis in Ontario, Canada.

J Am Acad Dermatol 2021;84:1302-9.

16. Dhana A, Yen H, Yen H, Cho E. All-cause and cause-specific mortality in psoriasis: a systematic review and meta-analysis. J Am Acad Dermatol 2019;80:1332-43.

17. Ahlehoff $\mathrm{O}$, Gislason GH, Charlot M, et al. Psoriasis is associated with clinically significant cardiovascular risk: a Danish nationwide cohort study. J Intern Med 2011;270:147-57.

18. Wilson FC, Icen M, Crowson CS, McEvoy MT, Gabriel SE, Kremers HM. Time trends in epidemiology and characteristics of psoriatic arthritis over 3 decades: a population-based study. J Rheumatol 2009;36:361-7. 